\title{
KAJIAN DUA KELOMPOK DATA TANAH DARI HASIL UJI BOR DALAM PADA PROYEK JALAN TOL JKC
}

\author{
Stephen Edmon Wiyana ${ }^{1}$, Josephine Aristiti Setyarini ${ }^{2}$ dan Aniek Prihatiningsih ${ }^{3}$ \\ ${ }^{1}$ Program Studi Sarjana Teknik Sipil, Universitas Tarumanagara, Jl. Letjen S. Parman No.1 Jakarta \\ Email: stephen.edmon@yahoo.com \\ ${ }^{2}$ Program Studi Sarjana Teknik Sipil, Universitas Tarumanagara, Jl. Letjen S. Parman No.1 Jakarta \\ Email: josephine.setyarini@gmail.com \\ ${ }^{3}$ Program Studi Sarjana Teknik Sipil, Universitas Tarumanagara, Jl. Letjen S. Parman No.1 Jakarta \\ Email:aniekp@ft.untar.ac.id
}

\begin{abstract}
ABSTRAK
Pembangunan proyek konstruksi selalu diawali dengan soil investigation. Studi skripsi ini didasari pada pertanyaan berupa berapa lamakah hasil soil investigation itu bisa valid untuk digunakan sebagai dasar perhitungan konstruksi? Pada proyek Jalan Tol Jakarta Kunciran Cengkareng didapati dua data bor dalam dengan selisih 8 tahun. Klasifikasi jenis tanah pada proyek Jalan Tol Jakarta Kunciran Cengkareng mainroad, melalui kajian nilai N - SPT dari hasil bor dalam pada kedua data yang terdapat pada proyek tersebut. Nilai N - SPT pada kedua data dikaji berdasarkan faktor waktu selama 8 tahun, komposisi tanah berdasarkan data kedua bor dalam akan diperoleh kajian berupa, perubahan nilai N - SPT yang terjadi akan ditinjau berdasarkan lokasi mainroad, perubahan kedalaman tanah keras berdasarkan kedua data bor dalam pada lokasi mainroad juga akan diperoleh. Korelasi nilai $\mathrm{C}_{\mathrm{u}}$ dan $\phi$ berdasarkan data laboratorium pada lokasi ramp akan diperoleh berdasarkan hasil contoh tanah yang diperoleh dari proyek serta stratigrafi dari lapisan tanah berdasarkan kedua hasil bor dalam. Metode matematika sederhana akan diaplikasikan untuk memperoleh perbandingan komposisi dan perubahan nilai N - SPT, nilai korelasi akan diperoleh berdasarkan plot nilai kepada grafik Sowers dan Peck, kekuatan daya dukung akan diperoleh melalui perhitungan Meyerhoff 1976 dan program Allpile. Hasil yang diperoleh adalah data bor dalam lama sudah tidak valid setelah periode 8 tahun.
\end{abstract}

Kata kunci: boring, standard penetration test, stratigrafi, daya dukung, korelasi parameter tanah

\section{PENDAHULUAN}

\section{Latar belakang}

Studi ini akan membahas situasi tanah yang terdapat pada Proyek Jalan Tol Jakarta - Kunciran - Cengkareng, yang dilaksanakan pengujian data penyelidikan tanah pada tahun 2009 untuk perencanaan desain,--namun baru mulai direalisasikan pada tahun 2017 dengan melakukan uji bor dalam kembali pada bidang lahan yang akan dibangun.

Masalah yang terjadi pada proyek ini salah satunya adalah keterlambatan dimulainya pembangunan struktur setelah diperolehnya data tanah dari lapangan pada tahun 2009, sehingga diperlukan data tanah kembali pada tahun 2017, oleh karena itu dengan ketersediaan data tanah pada proyek Jalan Tol Jakarta - Kunciran - Cengkareng pada 8 tahun yang lalu, studi ini diharapkan mampu menunjukkan perubahan daya dukung tanah yang terjadi dalam periode tersebut signifikan untuk diadakannya uji ulang daya dukung tanah atau tidak, tergantung pada kondisi tanah yang ditinjau, dan efeknya terhadap desain tiang pancang yang akan digunakan pada proyek yang bersangkutan.

\section{Tujuan}

Tujuan dari penelitian ini adalah untuk mengkaji bagaimana hasil penyelidikan tanah berupa bor dalam yang dilakukan pada tahun 2009, kemudian pada saat konstruksi jalan tol dilaksanakan dilakukan kembali penyelidikan tanah, sehingga analisis yang akan ditinjau yaitu daya dukung tanah dan kedalaman tiang pancang maupun borepile sesuai dengan desain yang ada dengan lokasi STA $26+221$ - STA $38+937$. Data N-SPT yang didapat dari lokasi STA $1+850$ - STA $4+350$ (ramp 1, ramp 4) akan dikorelasikan untuk dua jenis parameter tanah yaitu kuat geser tanah $\left(\mathrm{C}_{\mathrm{u}}\right)$ dan sudut geser dalam $(\phi)$. Jenis tanah yang terdiri dari lempung, lanau, dan pasir juga dapat dikaji untuk menentukan perlapisan tanah menurut pengklasifikasian yang berlaku, sehingga hasil akhir berupa stratigafi tanah didapat untuk verifikasi kedalaman tiang yang didesain untuk memenuhi besarnya beban struktur yang akan dipikul oleh tiang tersebut. 


\section{Batasan masalah}

Lokasi yang dicakup untuk kajian sebatas STA $26+221$ - STA $38+937$ (mainroad) dan STA $1+850$ - STA 4 + 350 (ramp 1, ramp 4). Data penyelidikan tanah yang ditinjau hanya nilai N - SPT. Korelasi antara nilai N - SPT dengan parameter tanah $\mathrm{C}_{\mathrm{u}}$ dan $\phi$. Perhitungan kekuatan daya dukung menggunakan metode Meyerhoff 1976 dan program Allpile. Beban yang ditinjau hanya beban aksial. Data penyelidikan terdiri dari 84 titik boring dimana boring lama (2009) terdiri dari 32 titik dan boring baru (2017) terdiri dari 52 titik, dan terdapat 21 titik hasil uji sampel laboratorium.

\section{DASAR TEORI}

Kajian akan dilakukan pada uji boring dan hasil nilai N - SPT yang diperoleh, berdasarkan kedua hasil soil investigation yang diperoleh sehingga hasil - hasil dari rumusan masalah dapat diperoleh.

\section{Boring}

Sebanyak 32 titik bor telah dilaksanakan dengan kedalaman antara 20 sampai $40 \mathrm{~m}$ dan 52 titik bor telah dilaksanakan dengan kedalaman 30 sampai 50 m pada lokasi - lokasi yang direncanakan. Pemboran mesin sudah dapat dihentikan setelah diperoleh konfirmasi bahwa ketebalan lapisan pendukung yang reliable secara menerus mencapai 5 meter atau lebih dari sutau lapisan dengan nilai N (Standard Penetration Test) 50 atau lebih.

\section{Uji penetrasi standar (SPT)}

Standard penetration test merupakan suatu percobaan yang dilakukan secara langsung di lapangan untuk memeperoleh daya dukung tanah dengan cara memasukan tabung sampel (split spoon) atau juga dapat dikatakan bahwa SPT adalah sejenis percobaan dinamis dengan memasukan alat yang dinamakan split spoon yang terdiri dari sepatu pemotong besi dibagian bawah, sebuah tabung baja (dapat terbelah dua secara memanjang ditengah tabung), serta sebuah penyambung di puncaknya ke dalam tanah yang merupakan silinder baja terbuka yang membelah secara longitudinal menjadi dua bagian yang disatukan.

\section{Meyerhoff 1976}

Pada metode perhitungan Meyerhofff 1976 dapat dilakukan dengan menggunakan nilai N dari hasil uji SPT dengan mempertimbangkan jenis tanah dimana fondasi tiang akan dipancang apakah pada jenis tanah kohesi atau nonkohesi.

- Tanah Non - Kohesif

○ Daya dukung ujung tiang

$$
\mathrm{Q}_{\mathrm{p}}=40 \times \mathrm{N}-\mathrm{SPT} \times \frac{L b}{D} \times \mathrm{A}_{\mathrm{p}}
$$

- Daya dukung selimut tiang

$$
\mathrm{Q}_{\mathrm{s}}=2 \times \mathrm{N}-\mathrm{SPT} \times \mathrm{p} \times \mathrm{L}_{\mathrm{i}} \ldots \ldots
$$

Dimana, $\mathrm{Q}_{\mathrm{p}}=$ daya dukung ujung tiang, $\mathrm{Q}_{\mathrm{s}}=$ daya dukung selimut tiang, $\mathrm{N}=$ Jumlah pukulan $(\mathrm{N}-\mathrm{SPT}), \mathrm{L}_{\mathrm{i}}=$ panjang lapisan tanah, $\mathrm{p}=$ keliling tiang, $\mathrm{A}_{\mathrm{p}}=$ luas penampang tiang

- Tanah Kohesif

○ Daya dukung ujung tiang

$$
\mathrm{Q}_{\mathrm{p}}=9 \times \mathrm{C}_{\mathrm{u}} \times \mathrm{A}
$$

- Daya dukung selimut tiang

$$
\mathrm{Q}_{\mathrm{s}}=\alpha \times \mathrm{C}_{\mathrm{u}} \mathrm{p} \times \mathrm{L}_{\mathrm{i}}
$$

Dimana, $\mathrm{Q}_{\mathrm{p}}=$ daya dukung ujung tiang, $\mathrm{Q}_{\mathrm{s}}=$ daya dukung selimut tiang, $\mathrm{L}_{\mathrm{i}}=$ panjang lapisan tanah, $\mathrm{p}=\mathrm{keliling}$ tiang, $\alpha=$ koefisien adhesi antara tanah dan tiang, $\mathrm{C}_{\mathrm{u}}=$ kohesi undrained, $\mathrm{A}_{\mathrm{p}}=$ luas penampang tiang

\section{Korelasi nilai N - SPT}

Korelasi nilai $\mathrm{N}$ - SPT terhadap $\mathrm{C}_{\mathrm{u}}$ dan $\phi$ dapat diaplikasikan dengan menggunakan grafik Sowers dan Peck dibawah ini 


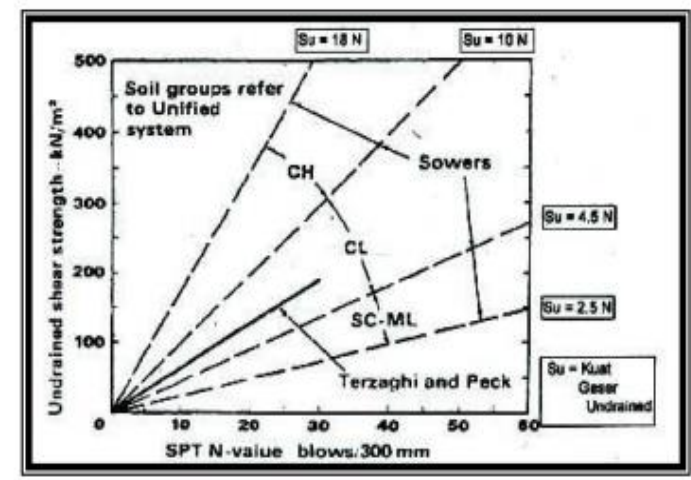

Gambar 1. Korelasi nilai N SPT vs Su (Terzaghi \& Peck, 1967; Sowers, 1979)

Sumber Terzaghi, K and Peck,R.B .(1967) "Soil Mechanics in Engineering Practice”.John Willey, New York

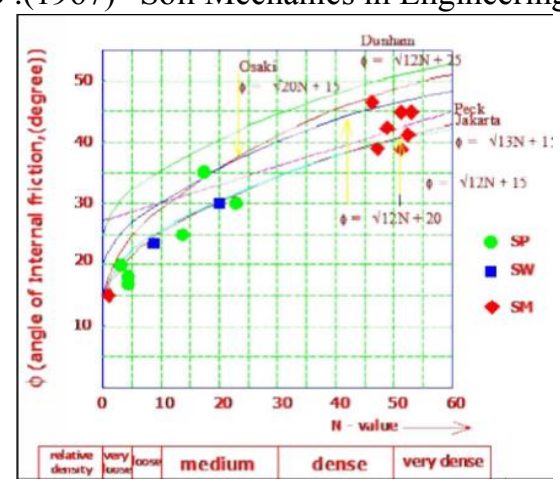

Gambar 2. Grafik N - SPT vs $\phi$ (Ohsaki, 1959)

Hatanaka,M dan Uchida,A,(1996),’Empirical Correlation Between Penetration Resistance and Internal Friction Angle of Sandy Soils", Soils and Foundations Vol 36, No4, 1-9 Dec, 1996.

\section{METODOLOGI PENELITIAN}

Metodologi penelitian dimulai dengan studi literatur terhadap topik - topik relevan dalam studi skripsi ini, dan kemudian dilanjutkan dengan pengambilan dan pengolahan data terhadap studi kasus yang akan dipelajari, selanjutnya data akan diolah dan dikaji berdasarkan rumusan masalah. 

pada Proyek Jalan Tol JKC

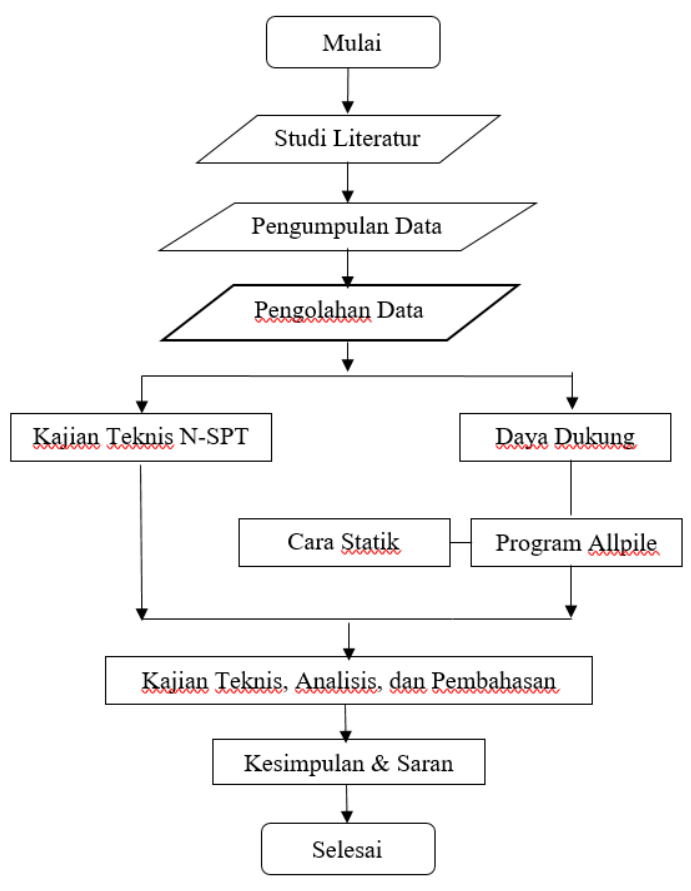

Gambar 3. Diagram Alir Pengerjaan Skripsi

\section{KAJIAN TEKNIS}

Kajian akan dibatasi terhadap lokasi mainroad dengan STA 26 + 221 - STA 38 + 937 yang akan dibagi lagi menjadi pembagian 5 area, sesuai dengan perbedaan jenis lokasi yang terdapat pada mainroad tersebut. Lokasi nya antara lain terdiri dari Husein 3, Garuda, Daan Mogot, Benda Utara, Kunciran.

\section{Klasifikasi Terzaghi}

Data boring yang dimiliki akan diberi keterangan berdasarkan dengan klasifikasi Terzaghi, dimana pembagian warnanya dapat dilihat sebagai berikut:

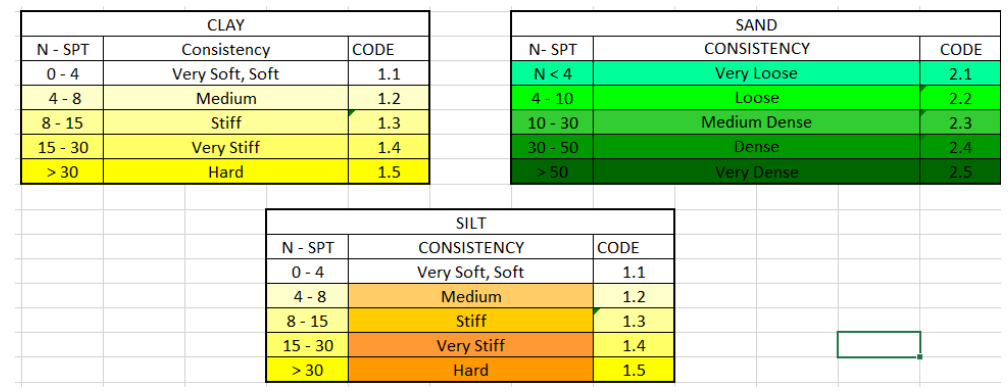

Gambar 4. Klasifikasi Jenis Tanah Berdasarkan Terzaghi 
Hasil dari klasifikasi jenis tanah terhadap boring lama dan boring baru dapat dilihat sebagai berikut:

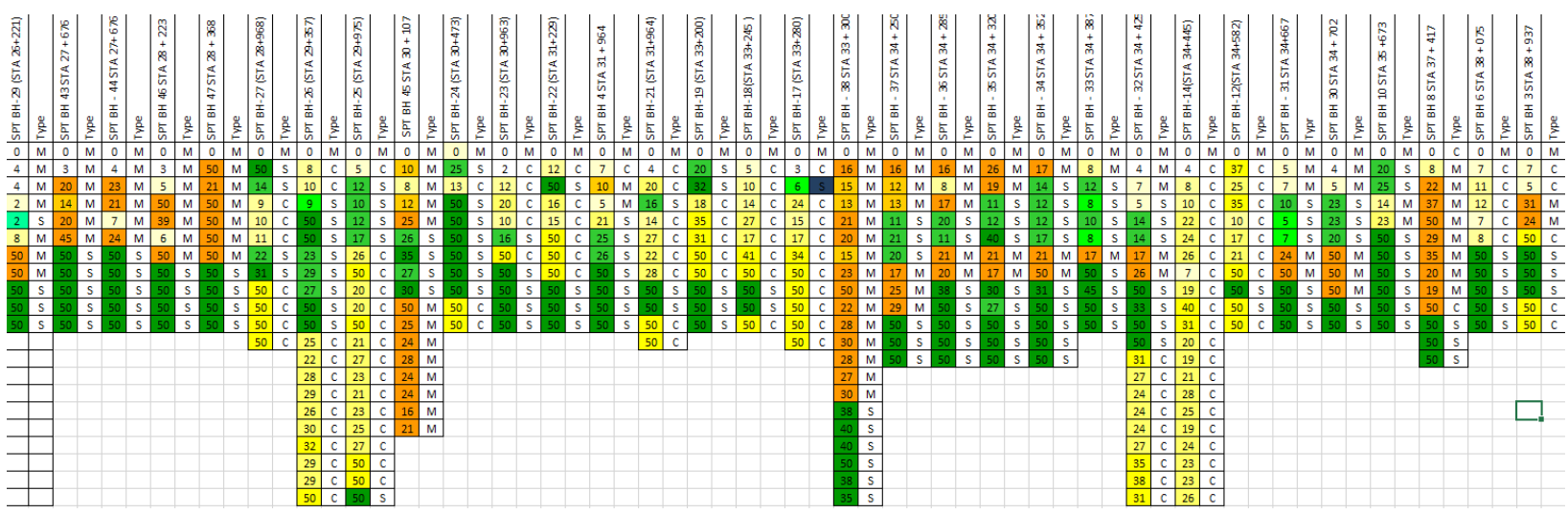

Gambar 5. Data Boring Lama

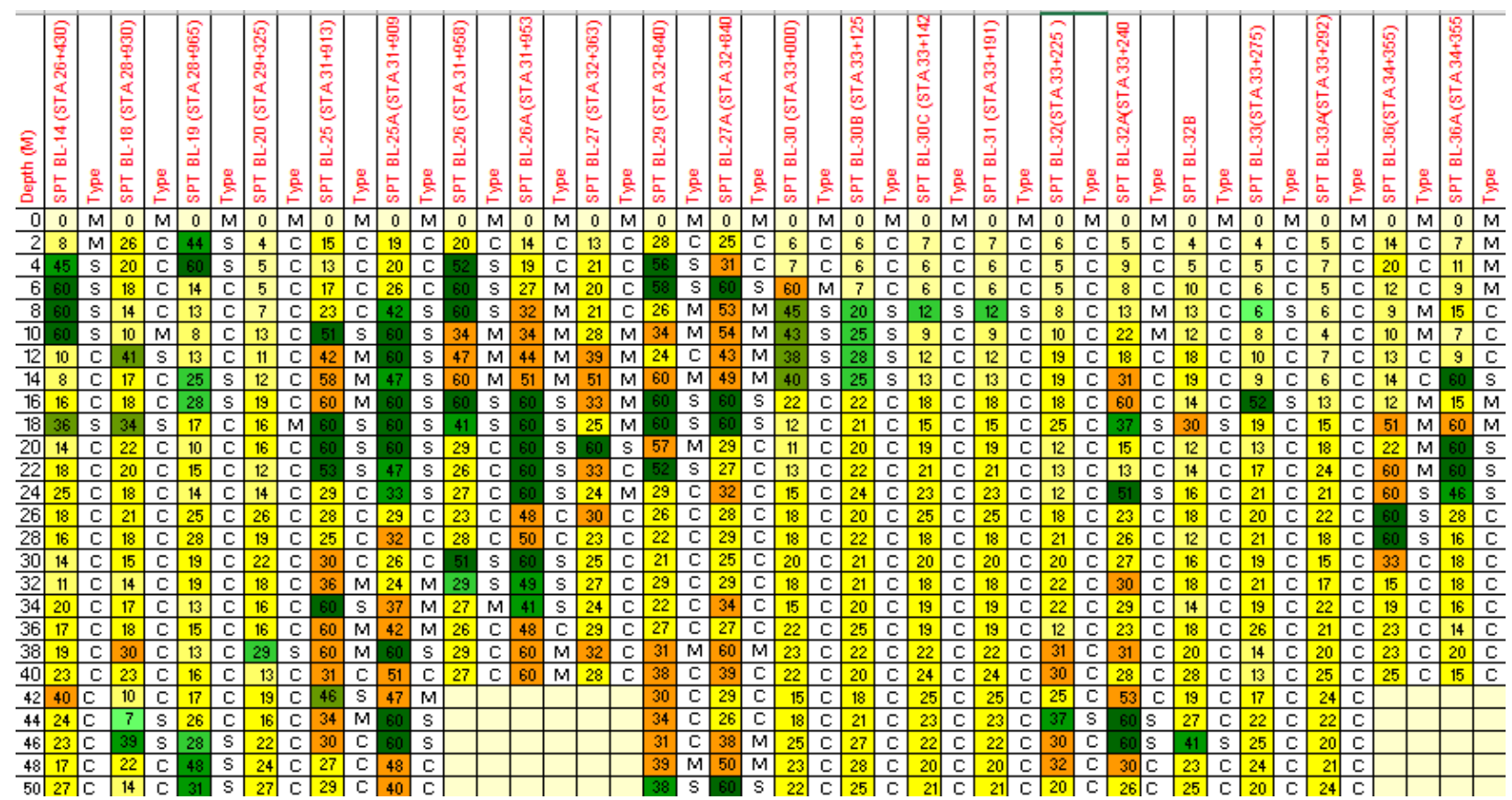

Gambar 6. Data Boring Baru

\section{Kajian teknis nilai N - SPT terhadap boring lama dan boring baru}

Nilai N - SPT tiap boring akan dikaji sehingga komposisi tanah pada tiap boring dapat diperoleh untuk mengetahui perubahan komposisi tanah berdasarkan persentase. Contoh terhadap pembagian komposisi jenis tanah clay pada boring lama dapat dilihat pada tabel berikut:

Tabel 1. Tabel Persentase Nilai N - SPT Jenis Tanah Clay Boring Lama

\begin{tabular}{|c|c|c|c|c|}
\hline Nilai N - SPT & Code & $\begin{array}{c}\text { Jumlah N - } \\
\text { SPT }\end{array}$ & $\begin{array}{c}\text { Jumlah N - } \\
\text { SPT } \\
\text { Keseluruhan }\end{array}$ & Persentase \\
\hline $0-4$ (Clay) & 1.1 & 4 & 130 & $3.1 \%$ \\
\hline $4-8$ (Clay) & 1.2 & 11 & 130 & $8.5 \%$ \\
\hline $8-15$ (Clay) & 1.3 & 17 & 130 & $13.1 \%$ \\
\hline $15-30$ (Clay) & 1.4 & 51 & 130 & $39.2 \%$ \\
\hline$>30$ (Clay) & 1.5 & 47 & 130 & $36.2 \%$ \\
\hline
\end{tabular}




\section{Kajian teknis terhadap perubahan nilai N - SPT}

Nilai N - SPT yang dikaji merupakan nilai N - SPT antara titik boring lama dan boring baru pada lokasi yang sama, dengan selisih jarak STA terpendek, contoh dari kajian dapat dilihat pada gambar berikut:

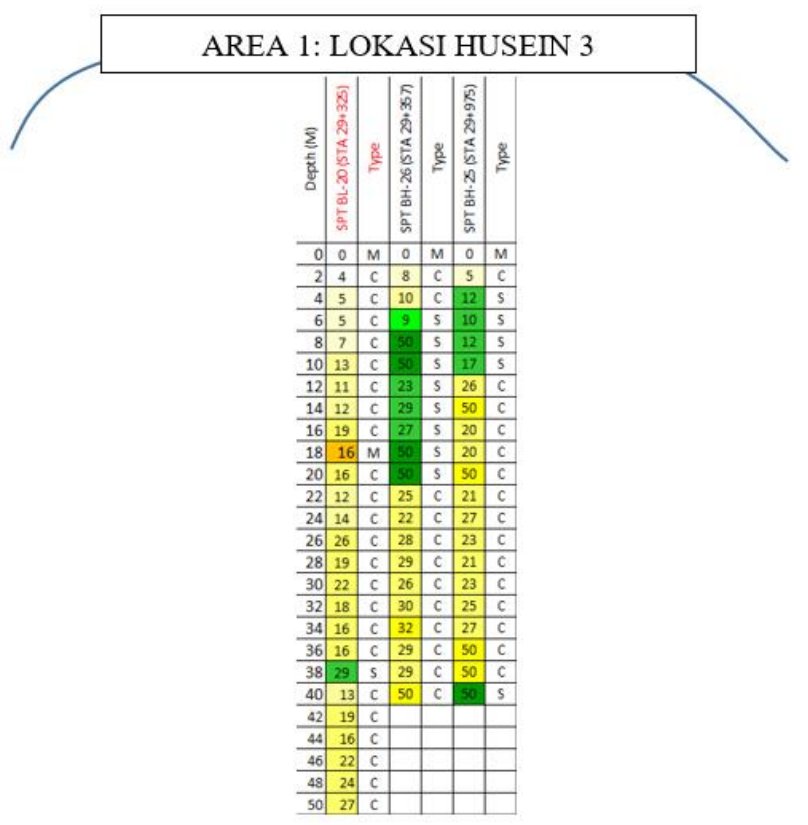

Gambar 7. Data Boring Area 1 STA $29+325$ - STA $29+975$

Perbandingan nilai N - SPT diaplikasikan terhadap BH26 dan BL20, hasil perubahan nilai N - SPT dapat dilihat sebagai berikut:

Berikut adalah hasil kajian perubahan nilai $\mathrm{N}-\mathrm{SPT}$ pada area 1:

1. Kedalaman 2 meter: Peningkatan nilai N - SPT $100 \%$

2. Kedalaman 4 meter: Tidak dapat diklasifikasi

3. Kedalaman 6 meter: Tidak dapat diklasifikasi

4. Kedalaman 8 meter: Tidak dapat diklasifikasi

5. Kedalaman 10 meter: Tidak dapat diklasifikasi

6. Kedalaman 12 meter: Tidak dapat diklasifikasi

7. Kedalaman 14 meter: Tidak dapat diklasifikasi

8. Kedalaman 16 meter: Tidak dapat diklasifikasi

9. Kedalaman 18 meter: Tidak dapat diklasifikasi

10. Kedalaman 20 meter: Tidak dapat diklasifikasi

11. Kedalaman 22 meter: Peningkatan nilai N-SPT $108 \%$

12. Kedalaman 24 meter: Peningkatan nilai N - SPT $57 \%$

13. Kedalaman 26 meter: Peningkatan nilai N-SPT $8 \%$

14. Kedalaman 28 meter: Peningkatan nilai N-SPT $52 \%$

15. Kedalaman 30 meter: Peningkatan nilai N-SPT $4 \%$

16. Kedalaman 32 meter: Peningkatan nilai N-SPT $67 \%$

17. Kedalaman 34 meter: Peningkatan nilai N-SPT $81 \%$

18. Kedalaman 36m: Peningkatan nilai N-SPT $81 \%$

19. Kedalaman 38m: Tidak dapat diklasifikasi

20. Kedalaman 40m: Tidak dapat diklasifikasi

Perubahan nilai N - SPT terhadap nilai N - SPT yang dapat diklasifikasi sebesar $62 \%$ berasal dari perbandingan 9 data, dimana 11 data lainnya tidak dapat diklasifikasi karena terjadi perubahan jenis tanah. 


\section{Korelasi Nilai N - SPT}

Korelasi nilai $\mathrm{N}$ - SPT terhadap $\mathrm{C}_{\mathrm{u}}$ dan $\phi$ dapat dilihat pada gambar berikut:

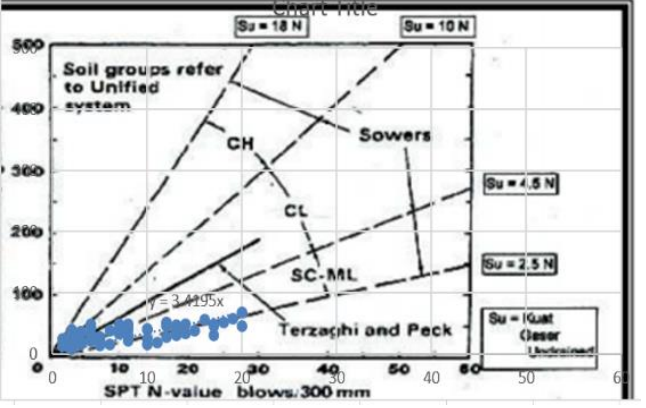

Gambar 9. Grafik Sowers Hubungan $\mathrm{N}-\mathrm{SPT}$ dan $\mathrm{C}_{\mathrm{u}}$

Berdasarkan grafik sowers diatas diperoleh nilai N - SPT korelasi terhadap Cu sebesar 3.5N kN/m².

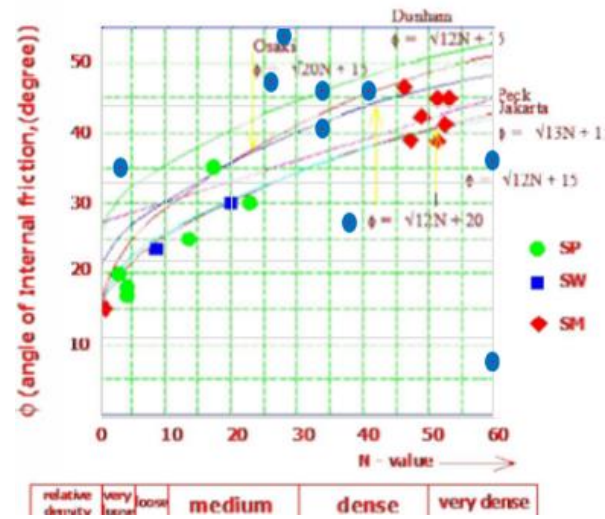

Berdasarkan grafik diatas diperoleh nilai $\mathrm{N}-\mathrm{SPT}$ korelasi terhadap $\phi$ sebesar $\sqrt{12 x N}+20$ degree.

\section{Perhitungan Daya Dukung}

Perhitungan daya dukung akan menggunakan contoh kasus area 2 sebagai kajian, dengan metode pemilihan pasangan boring lama dan baru sama dengan cara perbandingan nilai N - SPT pada sub bab sebelumnya.hasil perhitungan Meyerhoff 1976 dan Allpile dengan tipe tiang pancang dengan ukuran diameter $60 \mathrm{~cm}$, dapat dilihat pada tabel berikut:

Tabel 2. Daya Dukung BL26

\begin{tabular}{|c|c|c|c|c|c|c|c|c|c|c|c|}
\hline \multirow{2}{*}{$\begin{array}{c}\text { Depth } \\
(\mathrm{m})\end{array}$} & \multirow{2}{*}{ Lapisan Tanah } & \multirow{2}{*}{$\mathrm{N}$} & \multirow{2}{*}{$\begin{array}{c}\mathrm{N} \\
\text { Koreksi }\end{array}$} & \multirow{2}{*}{$\mathrm{Cu}$} & \multirow{2}{*}{$\alpha$} & \multicolumn{2}{|c|}{ Skin Friction $(\mathrm{kN})$} & \multirow{2}{*}{$\begin{array}{l}\text { End } \\
\text { Bearing } \\
\text { (kN) }\end{array}$} & \multirow{2}{*}{$\begin{array}{l}\text { Qull } \\
(\mathrm{kN})\end{array}$} & \multirow{2}{*}{$\begin{array}{l}\text { Qull } \\
\text { (ton) }\end{array}$} & \multirow{2}{*}{ Qall Allpile (ton) } \\
\hline & & & & & & Lokal & Kumulatif & & & & \\
\hline 0 & Clay & 0 & 0 & 0 & 1 & 0.0 & 0.0 & 0.0 & 0.0 & 0.0 & 0.0 \\
\hline 2 & Clay & 20 & 13 & 78.75 & 0.73 & 216.6 & 216.6 & 200.3 & 416.9 & 41.7 & 33.8 \\
\hline 4 & Sand & 52 & 34 & & & 257.2 & 473.8 & 1285.8 & 1759.6 & 176.0 & 175.25 \\
\hline 6 & Sand & 60 & 39 & & & 296.7 & 770.5 & 1483.7 & 2254.2 & 225.4 & 224.4 \\
\hline 8 & Sand & 60 & 39 & & & 296.7 & 1067.2 & 1483.7 & 2550.9 & 255.1 & 232.8 \\
\hline 10 & Silt & 34 & 25 & 151.7 & 0.37 & 190.6 & 1257.8 & 385.9 & 1643.7 & 164.4 & 144.9 \\
\hline 12 & Silt & 47 & 35 & 209.7 & 0.34 & 263.4 & 1521.2 & 533.4 & 2054.7 & 205.5 & 267.1 \\
\hline 14 & Silt & 60 & 50 & 299.3 & 0.27 & 375.9 & 1897.1 & 761.1 & 2658.2 & 265.8 & 278.5 \\
\hline 16 & Sand & 60 & 50 & & & 375.9 & 2273.0 & 1879.3 & 4152.2 & 415.2 & 485.3 \\
\hline 18 & Sand & 41 & 34 & & & 256.8 & 2529.8 & 1284.2 & 3814.0 & 381.4 & 481.4 \\
\hline 20 & Clay & 29 & 24 & 144.6 & & 181.7 & 2711.5 & 367.9 & 3079.3 & 307.9 & 376.5 \\
\hline 22 & Clay & 26 & 23 & 136.5 & 0.41 & 210.9 & 2922.3 & 347.2 & 3269.5 & 327.0 & 336.8 \\
\hline 24 & Clay & 27 & 24 & 141.75 & 0.4 & 213.6 & 3136.0 & 360.5 & 3496.5 & 349.7 & 378.67 \\
\hline 26 & Clay & 23 & 20 & 120.75 & 0.43 & 195.6 & 3331.6 & 307.1 & 3638.7 & 363.9 & 378.7 \\
\hline 28 & Clay & 28 & 25 & 147 & 0.39 & 216.0 & 3547.6 & 373.9 & 3921.5 & 392.2 & 419.7 \\
\hline 30 & Sand & 51 & 45 & & & 336.3 & 3883.9 & 1681.5 & 5565.4 & 556.5 & 559.6 \\
\hline 32 & Sand & 29 & 25 & & & 191.2 & 4075.2 & 956.1 & 5031.3 & 503.1 & 503.8 \\
\hline 34 & Clay & 27 & 24 & 141.75 & 0.39 & 208.3 & 4283.5 & 360.5 & 4644.0 & 464.4 & 469.7 \\
\hline 36 & Clay & 26 & 23 & 136.5 & 0.41 & 210.9 & 4494.3 & 347.2 & 4841.5 & 484.2 & 495.8 \\
\hline 38 & Clay & 29 & 25 & 152.25 & 0.36 & 206.5 & 4700.9 & 387.2 & 5088.1 & 508.8 & 576.2 \\
\hline 40 & Clay & 27 & 24 & 141.75 & 0.39 & 208.3 & 4909.2 & 360.5 & 5269.7 & 527.0 & 545.7 \\
\hline
\end{tabular}


Tabel 3. Daya Dukung BH21

\begin{tabular}{|c|c|c|c|c|c|c|c|c|c|c|c|}
\hline \multirow{2}{*}{$\begin{array}{l}\text { Depth } \\
\text { (m) }\end{array}$} & \multirow{2}{*}{ Lapisan Tanah } & \multirow{2}{*}{$\mathrm{N}$} & \multirow{2}{*}{$\begin{array}{c}\mathrm{N} \\
\text { Koreksi }\end{array}$} & \multirow{2}{*}{$\mathrm{Cu}$} & \multirow{2}{*}{$\alpha$} & \multicolumn{2}{|c|}{ Skin Friction (kN) } & \multirow{2}{*}{$\begin{array}{c}\text { End Bearing } \\
(\mathrm{kN})\end{array}$} & \multirow{2}{*}{ Qull $(\mathrm{kN})$} & \multirow{2}{*}{ Qull (ton) } & \multirow{2}{*}{ Qull Allpile (ton) } \\
\hline & & & & & & \begin{tabular}{l|} 
Lokal \\
\end{tabular} & Kumulatif & & & & \\
\hline 0 & Clay & 0 & 0 & 0 & 1 & 0.0 & 0.0 & 0.0 & 0.0 & 0.0 & 0 \\
\hline 2 & Clay & 4 & 3 & 15.8 & 1 & 59.3 & 59.3 & 40.1 & 99.4 & \begin{tabular}{c|c|}
9.9 \\
\end{tabular} & 23.29 \\
\hline 4 & Clay & 20 & 13 & 78.8 & 0.7 & 207.7 & 267.1 & 200.3 & 467.3 & 46.7 & 87.67 \\
\hline 6 & Sand & 16 & 11 & & & 79.1 & 346.2 & 395.6 & 741.8 & 74.2 & 126.09 \\
\hline 8 & Clay & 14 & 9 & 55.1 & 0.85 & 176.6 & 522.7 & 140.2 & 662.9 & $\begin{array}{ll}66.3 \\
\end{array}$ & 83.7 \\
\hline 10 & Clay & 27 & 20 & 120.5 & 0.575 & 261.0 & 783.8 & 306.4 & 1090.2 & 109.0 & 121.3 \\
\hline 12 & Clay & 22 & 16 & 98.2 & 0.475 & 175.7 & 959.5 & 249.7 & 1209.2 & 120.9 & 196.87 \\
\hline 14 & Clay & 28 & 23 & 139.7 & 0.4 & 210.5 & 1170.0 & 355.2 & 1525.2 & 152.5 & 193.3 \\
\hline 16 & Sand & 50 & 42 & & & 313.2 & 1483.2 & 1566.1 & 3049.3 & 304.9 & 283.3 \\
\hline 18 & Sand & 50 & 42 & & & 313.2 & 1796.4 & 1566.1 & 3362.5 & 336.2 & 328.7 \\
\hline 20 & Clay & 50 & 42 & 249.4 & 0.3 & 281.9 & 2078.3 & 634.3 & 2712.6 & 271.3 & 373.9 \\
\hline 22 & Clay & 50 & 44 & 262.5 & 0.43 & 425.3 & 2503.6 & 667.6 & 3171.3 & 317.1 & 431.8 \\
\hline
\end{tabular}

Kajian desain kedalaman tiang terhadap data boring lama dan boring baru diatas membuktikan bahwa terjadi penurunan tanah keras pada area 2 garuda sedalam 2 meter yaitu dari desain kedalaman berdasarkan boring lama 16 meter dan desain kedalaman berdasarkan boring baru 18 meter

\section{KESIMPULAN}

Berdasarkan kajian data diatas diperoleh kesimpulan sebagai berikut:

1. Berdasarkan kajian jenis tanah pada boring lama dan boring baru, terjadi perubahan komposisi jenis tanah terhadap kedua hasil boring, dimana boring lama diperoleh jenis tanah dominan nya adalah jenis tanah Sand, dan boring baru jenis tanah dominan nya adalah Clay.

2. Tabel perubahan nilai $\mathrm{N}$ - SPT dan jenis tanah dalam persentase setiap pembagian area dapat dilihat sebagai berikut:

\begin{tabular}{|c|c|c|}
\hline Area & $\begin{array}{c}\text { \% Perubahan N - SPT pada Jenis } \\
\text { Tanah yang sama }\end{array}$ & $\begin{array}{c}\text { Kedalaman Perubahan Jenis Tanah } \\
(\mathrm{m})\end{array}$ \\
\hline Area 1 & $62 \%$ & $4,6,8,1,12,14,16,18,20,38,40$ \\
\hline Area 2 & $53 \%$ & $12,14,18,20$ \\
\hline Area 3 & $23 \%$ & $8,12,18,20$ \\
\hline Area 4 & $43 \%$ & $2,4,10,12,14,16,18,20$ \\
\hline Area 5 & $36 \%$ & $2,8,10,16,18,20$ \\
\hline
\end{tabular}

3. Nilai korelasi parameter tanah $\mathrm{Cu}$ terhadap $\mathrm{N}-$ SPT sebesar $2.5 \mathrm{~N}$ berdasarkan grafik Terzaghi Peck dan $3.5 \mathrm{~N}$ berdasarkan garis persamaan excel.

4. Nilai korelasi parameter tanah $\phi$ terhadap $\mathrm{N}-\mathrm{SPT}$ sebesar $\sqrt{12 x N}+20$ berdasarkan grafik Peck terhadap 21 data lab yang ada. 
5. Tabel perubahan desain kedalaman tiang berdasarkan data N - SPT boring lama dan baru dapat dilihat sebagai berikut:

\begin{tabular}{|c|c|c|c|}
\hline Area & $\begin{array}{c}\text { Kedalaman Desain } \\
\text { Lama (m) }\end{array}$ & $\begin{array}{c}\text { Kedalaman Desain } \\
\text { Baru (m) }\end{array}$ & $\begin{array}{c}\text { Penurunan } \\
\text { Kedalaman }(\mathrm{m})\end{array}$ \\
\hline Area 1 & 16 meter & 40 meter & 24 meter \\
\hline Area 2 & 16 meter & 18 meter & 2 meter \\
\hline Area 3 & 16 meter & 24 meter & 8 meter \\
\hline Area 4 & 12 meter & 22 meter & 10 meter \\
\hline Area 5 & 12 meter & 26 meter & 14 meter \\
\hline
\end{tabular}

6. Kajian yang dilakukan terhadap nilai $\mathrm{N}$ - SPT dan konsistensinya akan mempermudah penentuan lapisan tanah yang disebut stratigrafi.

7. Data boring lama dapat digunakan untuk mengisi stasioning kosong pada boring baru sebagai sarana pembantu penggambaran stratigrafi.

8. Penurunan tanah keras terjadi pada STA $30+000-31+000$ dimana kedalaman tanah keras pada boring lama terdapat di 14 meter - 18 meter dan pada boring baru menjadi kedalaman 18 meter - 22 meter.

\section{DAFTAR PUSTAKA}

Bowles, Joseph E. 1988. Analisa dan Desain Pondasi Jilid 1. Edisi Keempat. Jakarta: Penerbit Erlangga. (Diterjemahkan oleh: Pantur Silaban, Ph. D).

Das, Braja M. 1995. Mekanika Tanah (Prinsip - Prinsip Rekayasa Geoteknis) Jilid 2. Jakarta: Penerbit Erlanga. (Diterjemahkan Oleh: Noor Endah dan Indrasurya B. Mochtar).

Das, Braja M. 1999. Principles of Geotechnical Engineering Fourth Edition. Canada: Thomson Canada Limited.

Das, Braja M. 2007. Principles of Foundation Engineering Sixth Edition. Canada: Thomson Canada Limited.

Das, Braja M. 2010 Principles of Foundation Engineering. Edisi ke-8. Stanford:Cengage Learning.

Das, Braja M. 2011. Geotechnical Engineering Handbook. USA: J. Ross Publishing, Inc.

Das, Braja M. Khaled Sobhan, 2010. Principles of Geotechnical Engineering. Edisi ke-8. Stanford:Cengage Learning.

Desiana Vidayanti, Pintor T Simatupang, Sido Silalahi.2013. Korelasi Nilai N-Spt Dengan Parameter Kuat Geser Tanah Untuk Wilayah Jakarta Dan Sekitarnya. Program Studi Teknik Sipil, FTPD, Universitas Mercu Buana.

Joseph E. Bowles. 1993. Analisi dan Desain Pondasi. Jilid 1, Edisi ke - 2. Jakarta:Erlangga.

Karl Terzaghi.1987. Mekanika Tanah dalam Prakttek Rekayasa..Edisi ke 2. Jakarta:Erlangga.

PT Cipta Strada.2009. Laporan Survai Lapangan Geoteknik. Jilid - 1

Ralph B. Peck.1987 Mekanika Tanah dalam Prakttek Rekayasa..Edisi ke 2. Jakarta:Erlangga.

Sandjaja, Gregorius. 2015. Diktat Pondasi Tiang II. Jakarta: Universitas Tarumanagara.

Teng. Wayne C. 1977. Foundaton Design. New Delhi: Prentice Hall of India

Terzaghi, Karl dan Ralph B. Peck. 1987. Mekanika Tanah dalam Praktek Rekayasa Jilid 1. Edisi Kedua. Jakarta: Penerbit Erlangga.

Terzaghi, Karl dan Ralph B. Peck. 1991. Mekanika Tanah dalam Praktek Rekayasa Jilid -2. Edisi Kedua. Jakarta: Penerbit Erlangga. 